\title{
Bioavailability of particulate metal to zebra mussels: Biodynamic modelling shows that assimilation efficiencies are site-specific
}

\author{
Adeline Bourgeault ${ }^{a, b}$, Catherine Gourlay-Francé ${ }^{a, b, ~}{ }^{*}$, Cindy Priadi ${ }^{c}$, Sophie Ayrault ${ }^{c}$, \\ Marie-Hélène Tusseau-Vuillemin ${ }^{d}$
}

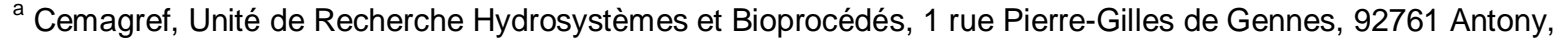 \\ France \\ ${ }^{\mathrm{b}}$ FIRE, FR-3020, 4 place Jussieu, 75005 Paris, France \\ ${ }^{c}$ LSCE/IPSL CEA-CNRS-UVSQ, Avenue de la Terrasse, 91198 Gif-sur-Yvette, France \\ d IFREMER Technopolis 40, 155 rue Jean-Jacques Rousseau, 92138 Issy-Les-Moulineaux, France \\ *: Corresponding author : Catherine Gourlay-Francé, Tel: +33 (0)1 40966163 ; Fax: +33 (0)1 40966199 ; \\ email address : catherine.gourlay@cemagref.fr \\ Email address : bourgeault@ensil.unilim.fr ; cindy.priadi@eng.ui.ac.id ; Sophie.Ayrault@Isce.ipsl.fr ; \\ Marie-helene.tusseau@ifremer.fr
}

\begin{abstract}
:
This study investigates the ability of the biodynamic model to predict the trophic bioaccumulation of cadmium (Cd), chromium ( $\mathrm{Cr}$ ), copper $(\mathrm{Cu})$, nickel $(\mathrm{Ni})$ and zinc $(\mathrm{Zn})$ in a freshwater bivalve. Zebra mussels were transplanted to three sites along the Seine River (France) and collected monthly for 11 months. Measurements of the metal body burdens in mussels were compared with the predictions from the biodynamic model. The exchangeable fraction of metal particles did not account for the bioavailability of particulate metals, since it did not capture the differences between sites. The assimilation efficiency (AE) parameter is necessary to take into account biotic factors influencing particulate metal bioavailability. The biodynamic model, applied with AEs from the literature, overestimated the measured concentrations in zebra mussels, the extent of overestimation being sitespecific. Therefore, an original methodology was proposed for in situ AE measurements for each site and metal.
\end{abstract}

\section{Highlights}

Exchangeable fraction of metal particles did not account for the bioavailability of particulate metals. Need for site-specific biodynamic parameters. Field-determined AE provide a good fit between the biodynamic model predictions and bioaccumulation measurements.

Keywords: Bioaccumulation ; Active biomonitoring Bioavailability of particulate metals ; Assimilation efficiency; Chemical sequential extraction 


\section{Introduction}

Most aquatic organisms are exposed to trace metals that are both dissolved in water and associated with suspended particles. The toxicokinetic-based biodynamic model is commonly employed to quantitatively investigate the metal bioaccumulation processes in aquatic invertebrates and to predict metal body burdens from environmental concentrations (CasadoMartinez et al., 2009; Cooper et al., 2010; Luoma and Rainbow, 2005; Pan and Wang, 2008; Roditi et al., 2000). This model was proved to predict both essential and non-essentials metals bioaccumulation by considering simultaneously the key processes leading to metal accumulation and elimination (Wang and Rainbow, 2008). This model describes the metal concentration in invertebrates as follows:

$$
\frac{d C_{o r g}}{d t}=k_{u} \cdot C_{w}+A E \cdot I R \cdot C_{f}-\left(k_{e}+g\right) \cdot C_{o r g}
$$

where $C_{o r g}$ is the metal concentration in the organism $\left(\mu \mathrm{g} \cdot \mathrm{g}^{-1}\right), t$ is the time of exposure $(\mathrm{d}), k_{u}$ is the uptake rate constant from the dissolved phase $\left(\mathrm{L}_{\mathrm{g}} \mathrm{g}^{-1} \cdot \mathrm{d}^{-1}\right), C_{w}$ is the concentration of bioavailable metal in the dissolved phase $\left(\mu \mathrm{g} . \mathrm{L}^{-1}\right), A E$ is the assimilation efficiency of ingested metal $(\%), I R$ is the ingestion rate $\left(\mathrm{g} \cdot \mathrm{g}^{-1} \cdot \mathrm{d}^{-1}\right), C_{f}$ is the metal concentration in the food $\left(\mu \mathrm{g} \cdot \mathrm{g}^{-1}\right), k_{e}$ is the efflux rate constant $\left(\mathrm{d}^{-1}\right)$ and $g$ is the growth rate constant of the animal $\left(\mathrm{d}^{-1}\right)$.

Using the biodynamic model to predict metal bioaccumulation requires information not only on the metal concentrations in water (both dissolved and particulate), but also on kinetic and physiological parameters that are usually determined experimentally in the laboratory and then used with field conditions. Among the latter, the assimilation efficiency (AE) - that corresponds to the fraction of ingested particulate metal that is actually retained in the tissue and the ingestion rate (IR) reflect diet-borne bioaccumulation and are of great importance in bioaccumulation modelling, especially for filter-feeding organisms such as mussels, for which food can be the predominant source of metals (Roditi et al., 2000; Wang and Fisher, 1998). 
For mussels, since they can select their food according to both its quality and its quantity (Arifin and Bendell-Young, 1997, 2000), the food actually ingested by the organisms can greatly vary from the suspended particles present in the water column making it challenging the measurement of realistic trophic parameters.

Beyond the critical aspects in ingestion rate evaluation, several studies have pointed out some limitations in using laboratory-determined AEs for the prediction of in situ diet-borne bioaccumulation. For instance, the geochemical properties of the water and the speciation of particulate metals are not correctly reproduced in the laboratory (Griscom et al., 2000; Wang and Fisher, 1998; Wang et al., 2002). Indeed, freshly spiked metals are generally found in the more easily exchangeable phase, whereas native metals are usually distributed in more residual phases (Wang et al., 2002). However, up to now, no generalization of geochemical and biological effects on AE has been established.

Other authors have investigated whether the bioavailability of particulate metals can be assessed through the chemical characterisation of an exchangeable metal fraction in particles (Bryan and Langston, 1992; Griscom and Fisher, 2004; Luoma, 1989; Stecko and BendellYoung, 2000). The operationally exchangeable metal fraction can be characterized by different protocols such as sequential extraction (Pueyo et al., 2001), digestive gut-fluid extraction (Mayer et al., 1996), $\mathrm{HCl}$ extraction (Luoma, 1989) or the Acid Volatile Sulfide / Simultaneously Extracted Metals (AVS/SEM) model (Di Toro et al., 1992). The AVS-based approach has lately been proposed as a regulatory tool to assess metal bioavailability in sediments (Ahlf et al., 2009), despite some reported exceptions (De Jonge et al., 2010; Griscom et al., 2000). The relationship between digestive gut-fluid or weak acid extractions and $\mathrm{AE}$ is also questionable: although it has been established for $\mathrm{Cd}$, the exchangeable metal fraction (whether evaluated by acids or gut juice) is unrelated to $\mathrm{AE}$ in the case of $\mathrm{Cr}$ and $\mathrm{Zn}$ (Fan and Wang, 2003; Wang et al., 2002). 
The objective of the present study was to assess the actual bioavailability of particulate metals to zebra mussels in rivers, by comparing observed versus predicted bioaccumulation. Zebra mussels were transplanted for 11 months to three sites along the Seine River, and monitored monthly. Meanwhile, metal concentrations were also monitored in water and suspended particles. The metal body burdens measured in mussel tissues were compared with biodynamic model predictions. We first investigated whether - and if so, to what extent chemical sequential extraction could mimic the bioavailability of particulate metals. We also tested the ability of the biodynamic model to do so when combined with laboratorydetermined parameters. This led us to propose an alternative methodology to estimate AE directly from field measurements.

\section{Materials and methods}

\subsection{Study area and sampling}

Three sites were studied along the Seine River (France): Marnay-sur-Seine (Site 1), Bougival (Site 2) and Triel-sur-Seine (Site 3). Site 1 is located $200 \mathrm{~km}$ upstream from Paris while Sites 2 and 3 are situated respectively $40 \mathrm{~km}$ and $80 \mathrm{~km}$ downstream from Paris. Site 2 and 3 are thus both subjected to diffuse urban contamination (i.e. atmospheric fallout combined with sewer overflows). In addition to this, Site 3 is also subject to wastewater discharges (domestic and industrial sewage).

Zebra mussels were collected in October 2008 from a reference site in the Meuse-Marne canal (France) $\left(48^{\circ} 45^{\prime} 33^{\prime \prime} \mathrm{N}, 5^{\circ} 36^{\prime} 05^{\prime \prime} \mathrm{W}\right)$, one day before deployment. The background metal levels in the zebra mussels are reported in Supporting Information (Table S1). Mussels (20-22 mm in shell length) were distributed in 33 cages (25 mussels per cage) and then transplanted onto 
the three sites. During an 11-month period, one cage was sampled per site each month and brought back to the laboratory in field water within a few hours.

On the same dates as mussels were sampled, water samples were collected monthly to monitor physico-chemical parameters (i.e. dissolved and particulate organic carbon, chlorophyll, pheopigment, total suspended solids (TSS), ash free dry weight (AFDW) which allows to assess the percentage of carbon in particles, major ions, temperature, conductivity and $\mathrm{pH})$.

The one-month integrative metal contamination was monitored using three Diffusive Gradient in Thin film technique (DGT) to assess dissolved labile metals (Davison and Zhang, 1994; Tusseau-Vuillemin et al., 2007) and using sediment traps for particulate metals. DGTs were composed by resin and restricted diffusive gel of $0.8 \mathrm{~mm}$ thickness (DGT research, Landcaster, UK) covered with a $0.45 \mathrm{~mm}$ polyethersulfone (PES) filter and a $0.4 \mu \mathrm{m}$ polycarbonate filter (Tusseau-Vuillemin et al., 2007). The sediment trap consisted of a $2 \mathrm{~L}$ polyethylene terephtalate (PET) bottle with two holes of a diameter of about $4 \mathrm{~cm}$ carved on both sides on the upper side of the bottle allowing water flow.

\subsection{Filtration rate measurement}

Once brought back to the laboratory, the mussels were used for field filtration rate $(F R)$ estimations. Extrapolating laboratory filtration rate to the field has to be done cautiously since the filtration activity of mussels is complex, depending on the water chemistry (Bourgeault et al., 2010a), the particles concentrations and the temperature (Reeders and Bij de Vaate, 1990). For each site, in the laboratory, the apparent filtration rate $\left(F R_{a p p}\right)$ was measured in filtered field water spiked with $1.10^{6}$ cells.mL $\mathrm{m}^{-1}$ of algae (Selenastrum capricornutum) as described in Bourgeault et al. (2010a). The quantification of FR with controlled TSS is necessary to get reliable measurement of particle decrease. Moreover, as observed by Roditi et al. (1996), the 
filtration rate does not depend on relative proportion of chlorophyll and suspended particles. The algae addition corresponds to a TSS concentration of $20 \mathrm{mg} \cdot \mathrm{L}^{-1}$ (TSS concentrations measured in situ during the whole campaign ranged from 4 to $\left.45 \mathrm{mg} . \mathrm{L}^{-1}\right)$. Three replicates of 5 pooled mussels were placed on a nylon sieve in a $500 \mathrm{~mL}$ beaker. The medium was continuously homogenized using a magnetic stirrer $(300 \mathrm{rpm})$ and the experiments were conducted in a thermostated room, adjusted to the site water's temperature.

The field filtration rate $F R$ was deduced from $F R_{a p p}$ by taking into account the actual TSS concentration in the field, based on the empirical relation obtained by Reeders and Bij de Vaate (1990):

$$
F R=F R_{\text {app }} \cdot e^{-0.037 \cdot\left(T S S_{\text {Field }}-T S S_{\text {Laboratory }}\right)}
$$

\subsection{Condition Index}

The soft tissues of mussels were removed from the shell and byssus threads were cut off. Soft tissues and shells were individually weighed. The Condition Index (CI) was calculated as the ratio between the wet weight of soft tissues and the total weight of the mussel (including the shell $)(n=25)$.

\subsection{Metal analysis}

The tissues of mussels were then freeze-dried and weighed. The dried tissues were pooled for a given date and site and homogenized (MM 400 Retsch). About $80 \mathrm{mg}$ of the homogenized tissues were digested for $1.5 \mathrm{~h}$ in polypropylene tubes (Sarstedt) with $2 \mathrm{~mL}$ of $\mathrm{HNO}_{3}\left(65 \%\right.$ suprapur Merck) using a heating block (DigiPREP, SCP Science) set at $95^{\circ} \mathrm{C}$. After cooling, $0.8 \mathrm{~mL}$ of $\mathrm{H}_{2} \mathrm{O}_{2}$ (30\% suprapur Merck) were added and the sample was once 
again heated for $1.5 \mathrm{~h}$ at $95^{\circ} \mathrm{C}$. Finally, $17.2 \mathrm{~mL}$ of ultrapure water (Elga) were added to the extract.

After retrieval, the chelex resins of DGTs were eluted in 1M nitric acid (Suprapur, Merck) in which the analysis was performed. The monthly average labile concentrations were determined as described by Tusseau-Vuillemin et al. (2007).

Particles collected by sediment traps were centrifuged, freeze-dried and then subjected to two treatments. The freeze-drying may cause re-distribution of speciation, nevertheless it was taken as a measure to make uniform sample condition and avoid poor reproducibility due to variability in moisture contents.

The first treatment consisted of total digestion, where the analysis of total metal concentration in suspended matter was performed for the entire 11-month exposure by Priadi et al. (2011a). The second treatment consisted of sequential extraction following the Community Bureau of Reference (BCR) scheme (Pueyo et al., 2001). Particulate metals were operationally-divided as exchangeable (Exch), reducible (Red), oxidizable (Oxy) and residual (Res) fractions. The percentage of metal extracted for each fraction was considered constant during the exposure for a given site (Priadi et al., 2011a). Among the 11-month exposure, BCR extractions in suspended particles were not performed in November and December 2008 and in June and September 2009. These four missing values were extrapolated, based on the average percentage in each fraction of the sequential extraction and total particulate concentrations.

In the present study, the exchangeable and the reducible fractions were considered representative of the mobile particulate metals since the operational conditions of the first two extraction steps are similar to the $\mathrm{HCl}$ extraction conditions (Larner et al., 2008) recommended by Luoma et al. (Luoma, 1989) to operationally assess particulate metal bioavailability. 
Metal concentrations were determined using an Inductively Coupled Plasma-Mass Spectrometer (ICP-MS ThermoFisher Scientific), checking the accuracy of the analytical procedure with a reference natural water sample (NIST 1640). Internal standards $\left({ }^{103} \mathrm{Rh},{ }^{115} \mathrm{In}\right.$ and ${ }^{185} \mathrm{Re}$ ) were added to the samples prior to metal analysis. The relative standard deviations were $<15 \%$ for $\mathrm{Cr}, \mathrm{Ni}, \mathrm{Cu}$ and $\mathrm{Cd}$, and $<27 \%$ for $\mathrm{Zn}(n=5)$. A reference mussel material (Mussel Tissue ERM-CE 278) was also used to validate the acidic digestion. The deviation from certified values was $<10 \%$ for $\mathrm{Cr}, \mathrm{Cd}, \mathrm{Cu}$ and $\mathrm{Zn}(n=4)$, except for one sample in the case of $\mathrm{Cr}$, where the deviation reached $31 \%$. Ni concentration is not referenced in this mussel material. Metal body burden was expressed in $\mu \mathrm{g}$ of metal per $\mathrm{g}$ of dry tissue $\left(\mu \mathrm{g} \cdot \mathrm{g}_{\mathrm{dry} w t}{ }^{-1}\right)$. Since the 25 mussels were pooled for one site and one date, we assumed a $10 \%$ deviation for the metal analysis in mussel tissues, based on the results obtained by Bervoets et al. (Bervoets et al., 2004), who showed that a representative sample with an RSD lower than $10 \%$ was obtained with 15 pooled individuals. It is important to notice that this deviation reflects both biological and analytical variability. Our measurements on the reference mussel material confirmed the RSD imputable to analytical variability was lower than $10 \%(n=4)$.

\subsection{Statistical analysis}

All data was first tested for normality using the Shapiro-Wilkinson test. Significant differences in trace metal body burdens and filtration rates at different date and site were tested using the Kruskal-Wallis analysis. The normally-distributed Condition Indexes were compared using analyses of variance (ANOVA) followed by the Tukey HSD test. A probability level of 0.05 was considered to be statistically significant. 


\section{Bioaccumulation modelling}

To apply the biodynamic model to monthly data, metal bioaccumulation in mussels was predicted from Equation 1, under the hypothesis that environmental variables (i.e. TSS concentration, $\mathrm{C}_{\mathrm{w}}$ and $\mathrm{C}_{\mathrm{f}}$ ), physiological parameter (IR= FR x TSS and g) are constant between $t_{i-1}$ and $t_{i}$, but may vary from month to month. The metal concentration in mussel tissues is described by the following equation (details of the resolution of the differential equation are reported in SI):

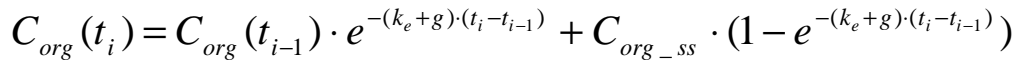

$$
\begin{aligned}
& \text { where } C_{\text {org_ss }}=\frac{k_{u} \cdot C_{w}+A E \cdot T S S \cdot F R \cdot C_{f}}{k_{e}+g}
\end{aligned}
$$

$C_{\text {org }}$ being the metal concentration in the organism $\left(\mu \mathrm{g} \cdot \mathrm{g}^{-1}\right), C_{w}$ the bioavailable dissolved metal concentration between $t_{i-1}$ and $t_{i}\left(\mu \mathrm{g} . \mathrm{L}^{-1}\right)$ which was approximated by DGT-labile metal concentrations (Ferreira et al., 2008; Tusseau-Vuillemin et al., 2004), $C_{f}$ the metal concentration of the particles collected by the sediment traps between $t_{i-1}$ and $t_{i}\left(\mu \mathrm{g} . \mathrm{g}^{-1}\right), k_{u}$ the uptake rate constant from the dissolved phase $\left(\mathrm{L} \cdot \mathrm{g}^{-1} \cdot \mathrm{d}^{-1}\right), A E$ the assimilation efficiency of ingested metal (\%), TSS the Total Suspended Solid concentration obtained by averaging the values measured at $t_{i-l}$ and $t_{i}\left(\mathrm{~g} \cdot \mathrm{L}^{-1}\right), F R$ the filtration rate $\left(\mathrm{L} \cdot \mathrm{g}^{-1} \cdot \mathrm{d}^{-1}\right)$ measured as described in the Material and Methods section and also obtained by averaging the values measured at $t_{i-1}$ and $t_{i}, k_{e}$ the efflux rate constant $\left(\mathrm{d}^{-1}\right)$ and $g$ the growth rate constant $\left(\mathrm{d}^{-1}\right)$ between $t_{i-1}$ and $t_{i}$.

The ingestion rate (IR) was expressed as the product of TSS concentration and FR. The default assumption made here is that the ingested particles are similar to the particles sampled in the water column. Indeed, the possible selection of particles for ingestion could not be assessed in the field, unless gut content analysis was applied (Christie and Bendell, 2009). Moreover, the filtration rate (FR) of mussels was measured ex situ in filtered field water spiked with a standard food (algae), which can induce a slight but a substantial difference 
between the in situ and the ex situ FR. Given the inability to evaluate in situ true filtration rates, this approach was selected because of its simplicity. Other types of filtration activity of bivalves measurements often result in great disturbance of the mussels (isolation of siphons by a wall (Galstoff, 1928; Kryger and Riisgard, 1988)) and are obviously inaproppriate for in situ measurement.

Initial metal concentration in mussels $C_{\text {org }}\left(t_{0}\right)$ is the measured concentration in mussels at the collection site (see Table $\mathrm{S} 1$ ). The growth rate $g\left(\mathrm{~d}^{-1}\right)$ was calculated for each month from the evolution of the dry weight of the mussels' soft tissues between $t_{i-1}$ and $t_{i}$ divided by time and the initial weight of mussels at $t_{i-1}$. During spawning, weight loss leads to a negative growth rate. This implies that spawning concentrates the metals in soft tissues since evacuated gametes have a low metal content compared to the other soft parts, as observed by Phillips (1980).

The mean predicted metal accumulation was performed using the mean values of the biodynamic parameters summarized in Table 1. Parameters were obtained from several studies on zebra mussels (Bourgeault et al., 2011; Bourgeault et al., 2010a; Mersch et al., 1993; Roditi and Fisher, 1999) or marine mussels when not available for zebra mussels (Wang et al., 1996; Zaroogian and Johnson, 1984). As far as Cd and Cr are concerned, modelling was performed using biodynamic parameters determined for the zebra mussel by Roditi and Fisher (1999) except the uptake rate constants of $\mathrm{Cd}\left(k_{u}\right)$ which was determined in laboratory in a previous study and was expressed as a function of the filtration rate and $\mathrm{Ca}$ and $\mathrm{Zn}$ dissolved concentrations (Bourgeault et al., 2010a). The uptake rate constant of $\mathrm{Ni}$ was also determined as a function of the filtration rate and confounding factors (Bourgeault et al., 2011). Hence, for $\mathrm{Cd}$ and $\mathrm{Ni}, \mathrm{k}_{\mathrm{u}}$ varied from month to month and from sites. The accumulation of dissolved $\mathrm{Cu}$ was also studied in laboratory in a preliminary study (unpublished data). Cr speciation was not determined in the present study, that is why we 
used a mean of the respective $\mathrm{k}_{\mathrm{u}}$ of $\mathrm{Cr}(\mathrm{III})$ and $\mathrm{Cr}(\mathrm{VI})$ determined by Roditi and Fisher (1999). As biodynamic parameters were not determined for the zebra mussel for $\mathrm{Zn}$ we used the biodynamic parameters determined for the mussel M. edulis (Wang et al., 1996). Elimination rates $\mathrm{k}_{\mathrm{e}}$ for $\mathrm{Cu}$ and $\mathrm{Ni}$ were obtained from Mersch et al. (1993) and Zaroogian and Johnson studies (1984). When several AEs were reported in the literature, we chose the one which had been determined from natural seston which characteristics were the closest to the sites studied (i.e. TSS loads, particulate organic carbon and chlorophyll concentrations). Assimilation efficiencies for $\mathrm{Cu}$ and $\mathrm{Ni}$ were not available in the literature for zebra mussels or other closely related bivalve species.

In a first simulation, we evaluated the predictive capacity of the biodynamic model to determine the contamination of mussels with $\mathrm{AE}$ from the literature (Table 1) and the particulate metal concentrations as the concentration measured in the Exch + Red fractions. No simulations were made for $\mathrm{Cu}$ and $\mathrm{Ni}$, since no $\mathrm{AEs}$ were available.

In a subsequent simulation, the ability of the exchangeable fraction of the chemical sequential extractions to reflect the concentration of bioavailable particulate metal was investigated. The measured metal concentrations in mussels were compared to the predicted values with an $\mathrm{AE}$ equal to $100 \%$ and $C_{f}$ as the concentration of particulate metal measured in the Exch fraction.

Finally, data from the first 5 months of exposure was used to determine AE for each metal and each site, using an optimisation procedure (least squares method). Thus, from Eq. (3) and Eq. (4), AE was optimised to reduce the deviation of the predicted versus observed bioaccumulation of the first 5 months (solver of Excel software). The biodynamic model was then applied with optimized AEs to data from the last 6 months and predicted accumulation concentrations were compared to the measured ones. 
Table 1: Bio-kinetic parameters used to model metal concentrations in zebra mussel tissues. Values indicated in italic refs to parameters determined for marine mussels.

\begin{tabular}{llll} 
& $\mathrm{AE}(\%)$ & $\mathrm{k}_{\mathrm{u}}\left(\mathrm{L} \cdot \mathrm{g}^{-1} \cdot \mathrm{d}^{-1}\right)$ & $\mathrm{k}_{\mathrm{e}}\left(\mathrm{d}^{-1}\right)$ \\
$\mathrm{Cd}$ & $26 \pm 2^{\mathrm{a} 1}$ & $k_{u}=F R \cdot\left(\frac{0.134}{1+10^{3.5} \cdot[\mathrm{Ca}]+10^{7.4} \cdot[\mathrm{Zn}]}\right) \mathrm{b}$ & $0.012 \pm 0.001^{\mathrm{a} 3}$ \\
$\mathrm{Cr}$ & $1.5 \pm 0.5^{\mathrm{a} 2}$ & $1.15^{\mathrm{a}}$ & $0.015 \pm 0.002^{\mathrm{a} 3}$ \\
$\mathrm{Zn}$ & $32 \pm 5^{c 1}$ & $1.047^{c 2}$ & $0.018 \pm 0.004^{c 3}$ \\
$\mathrm{Ni}$ & $\mathrm{NA}$ & $k_{u}=F R \cdot\left(\frac{0.043}{1+10^{3.6} \cdot[\mathrm{Ca}]}\right) \mathrm{b}$ & $0.019^{d}$ \\
$\mathrm{Cu}$ & $\mathrm{NA}$ & $0.163^{\mathrm{b}}$ & $0.022^{\mathrm{e}}$ \\
\hline
\end{tabular}

NA : not available

${ }^{a}$ : (Roditi and Fisher, 1999)

${ }^{\text {al }}$ : AE referring to natural seston identified as 'seston B' in Roditi and Fisher study. This seston was sampled from the Hudson River, which had a TSS concentration of $11 \mathrm{mg} . \mathrm{L}^{-1}$. For a comparison purpose, the average TSS concentration was respectively 12, 14 and $10 \mathrm{mg} / \mathrm{L}$ for Site 1, 2 and 3 over the 11-month exposure.

${ }^{\text {a2 }}$ : AE reffering to natural seston identified as 'seston A' in Roditi and Fisher study,. This seston was sampled from the Hudson River, which had a TSS concentration of $28 \mathrm{mg} . \mathrm{L}^{-1}$ (AE for Cr was not available for 'seston B')

${ }^{a 3}$ : Mean of the respective $\mathrm{k}_{\mathrm{e}}$ of $\mathrm{Cr}$ III and $\mathrm{Cr}$ VI, obtained as a result of mussel contamination through the trophic and the dissolved pathways

b: (Bourgeault et al., 2011; Bourgeault et al., 2010a) and unpublished data for $\mathrm{Cu}$

${ }^{c}$ : (Wang et al., 1996)

${ }^{\mathrm{c}}$ : AE referring to the natural seston identified as seston of '11 March', which had physicochemical characteristics (chlorophyll concentration $=11,7 \mu \mathrm{g} . \mathrm{L}^{-1}$, TSS concentration $9.5 \mathrm{mg} \cdot \mathrm{L}^{-1}$ ) close to the characteristics measured at Site 1,2 and 3. Average concentrations measured at Sites 1, 2 and 3 were respectively $1.3,5.6$ and $5.4 \mu \mathrm{g} . \mathrm{L}^{-1}$ for chlorophyll and 12,14 and $10 \mathrm{mg} \cdot \mathrm{L}^{-1}$ for TSS.

${ }^{\mathrm{c} 2}:$ Mean $\mathrm{k}_{\mathrm{u}}$

${ }^{c 3}$ : Mean $\mathrm{k}_{\mathrm{e}}$ obtained as a result of mussel contamination through the trophic and the dissolved routes

d: (Zaroogian and Johnson, 1984)

e: (Mersch et al., 1993) 


\section{Results}

\subsection{Chemical Characterization}

The different chemical parameters measured over the exposure indicated a gradient from upstream (Site 1) to downstream (Site 2 and 3) (Table 2). Indeed the DOC, POC and chlorophyll concentrations are significantly higher downstream $(\mathrm{p}<0.05)$, as well as the percentage of organic carbon in the TSS although not statistically significant. A metal gradient was also observed since the labile and particulate metal concentrations were significantly higher at Sites 2 and 3 compared to Site 1 for $\mathrm{Cu}, \mathrm{Zn}$ and $\mathrm{Cd}(\mathrm{p}<0.05$, Kruskall Wallis analysis). A detailed description of metal contamination and variability is provided in Priadi et al. (Priadi et al., 2011b). 
Table 2: Physico-chemical parameters and metal concentrations measured at Site 1, 2 and 3 expressed as minimum - maximum and median in parenthesis.

\begin{tabular}{|c|c|c|c|}
\hline & \multirow{2}{*}{ Site 1} & \\
\hline & & Site 2 & Site 3 \\
\hline $\mathrm{Q}\left(\mathrm{m}^{3} \cdot \mathrm{s}^{-1}\right)$ & $25-89(50)$ & $92-324(184)$ & $198-550(340)$ \\
\hline $\mathrm{pH}$ & $8.06-8.32(8.18)$ & $7.20-8.24(7.91)$ & $7.10-8.01(7.73)$ \\
\hline Temperature $\left({ }^{\circ} \mathrm{C}\right)$ & $5.6-23(13.1)$ & $4.5-22.8(15.2)$ & $4.9-22(14.4)$ \\
\hline Conductivity $\left(\mu \mathrm{S} . \mathrm{cm}^{-1}\right)$ & $268-526(479)$ & $446-611(527)$ & $506-668(619)$ \\
\hline Alkalinity $\left(\mathrm{mg} \cdot \mathrm{L}^{-1}\right)$ & $152-287(238)$ & $182-281(244)$ & $189-281(253)$ \\
\hline DOC $\left(\mathrm{mg} \cdot \mathrm{L}^{-1}\right)$ & $1.62-2.68(2.05)$ & $2.56-4.34(2.94)$ & $3.42-5.45(3.87)$ \\
\hline TSS $\left(m g . L^{-1}\right)$ & $4.0-33.4(9.5)$ & $6.4-44.1(10.9)$ & $4.2-21.9(9.8)$ \\
\hline $\mathrm{C}$ in TSS $(\%)$ & $16-61(28)$ & $21-48(32)$ & $0-59(34)$ \\
\hline POC (mg. $\left.\mathrm{L}^{-1}\right)$ & $0.05-1.9(0.56)$ & $0.38-3.92(0.88)$ & $0.04-2.47(0.89)$ \\
\hline Chlorophyll $\left(\mu \mathrm{g} . \mathrm{L}^{-1}\right)$ & $0.5-3.5(1.0)$ & $0.4-15.1(3.7)$ & $0.3-16.4(2.5)$ \\
\hline Pheopigment $\left(\mu \mathrm{g} . \mathrm{L}^{-1}\right)$ & $0.9-7.5(1.3)$ & $0.8-17.3(1.7)$ & $0.3-2.5(1.4)$ \\
\hline \multicolumn{4}{|c|}{ Labile metal concentration $\left(\mu \mathrm{g} . \mathrm{L}^{-1}\right)$} \\
\hline $\mathrm{Cd}$ & $0-0.002(0.001)$ & $0-0.007(0.003)$ & $0-0.005(0.004)$ \\
\hline $\mathrm{Cr}$ & $0-0.035(0.020)$ & $0-0.093(0.028)$ & $0-0.086(0.031)$ \\
\hline $\mathrm{Zn}$ & $0-1.49(0.44)$ & $0-3.13(1.83)$ & $0-3.74(2.68)$ \\
\hline $\mathrm{Ni}$ & $0-0.212(0.173)$ & $0-0.47(0.322)$ & $0-0.796(0.543)$ \\
\hline $\mathrm{Cu}$ & $0-0.104(0.074)$ & $0-0.481(0.253)$ & $0-0.388(0.251)$ \\
\hline \multicolumn{4}{|c|}{$\begin{array}{l}\text { Particulate metal concentration } \\
\text { measured in the Exchangeable and } \\
\text { Reducible fractions }\left(\mu \mathrm{g} \cdot \mathrm{g}^{-1}\right)\end{array}$} \\
\hline $\mathrm{Cd}$ & $0.20-0.32(0.23)$ & $0.65-2.90(1.73)$ & $0.70-2.90(1.51)$ \\
\hline $\mathrm{Cr}$ & $0.27-1.43(1.03)$ & $\begin{array}{c}6.57-10.56(7.93) \\
236.55-377.07\end{array}$ & $2.00-10.02(7.20)$ \\
\hline $\mathrm{Zn}$ & $141.56-277.20(246.19)$ & $(305.30)$ & $141.56-277.20(246.19)$ \\
\hline $\mathrm{Ni}$ & $2.21-4.86(4.39)$ & $6.01-9.88(8.47)$ & $3.40-8.10(7.23)$ \\
\hline $\mathrm{Cu}$ & $2.08-7.68(2.42)$ & $16.70-61.22(37.77)$ & $9.04-38.89(18.40)$ \\
\hline
\end{tabular}

Q: discharge, DOC: Dissolved Organic Carbon, TSS: Total Suspended Solids, POC: Particulate Organic Carbon, C: carbon.

\subsection{Biological activity of mussels}

Condition index (CI) and filtration rate (FR) data is given in Figure 1 and 2.

From October 2008 to July 2009, the mean mortality rate was $<12 \%$. In August the mortality rates were 27,79 and $70 \%$ for Sites 1,2 and 3 respectively and then reached 88,88 and $92 \%$ in September. 
The CI exhibited a seasonal trend, with an increase over the first 6 months, reaching a maximum at the end of March $(0.45 \pm 0.03$ for Site 2$)$ or April $(0.40 \pm 0.04$ for Site 1 and $0.42 \pm 0.06$ for Site 3$)$, followed by a decrease until September $(0.19 \pm 0.02,0.25 \pm 0.05$ and $0.26 \pm 0.08$ for Sites 1,2 and 3 respectively). Hence we inferred that spawning occurred in April for Site 2 and in May for Sites 1 and 3.

The FR sharply dropped at the 3 sites in December and increased steadily from January to August. The water temperature, which fell below $5^{\circ} \mathrm{C}$ in December, could partly explain the decrease of FR during the winter (Reeders and Bij de Vaate, 1990). The FR at Site 1 was generally higher than at both other sites, the difference being significant in February and March (Kruskal and Wallis analysis, $\mathrm{p}<0.05)$. This may be explained by a lower food supply (Reeders and Bij de Vaate, 1990), since concentrations of dissolved and particulate organic matter were lower at Site 1 (Priadi et al., 2011b).

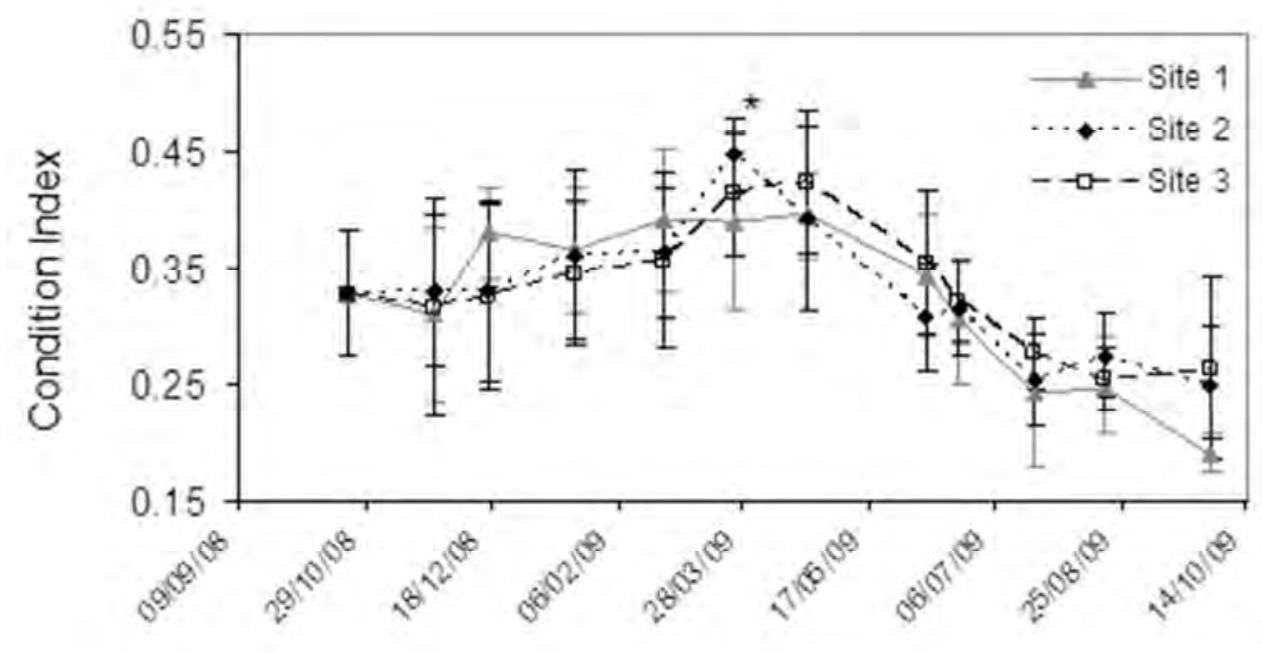

Figure 1: Condition Index (CI) of the mussels exposed at the three sites. Mean $\pm S D(n=15)$. * Maximal values for each of the three sites are significantly different from the initial $C I$ (except for Site 1) and from the final CI (except for Site 3), Anova-TukeyHSD ( $p<0.05)$. 


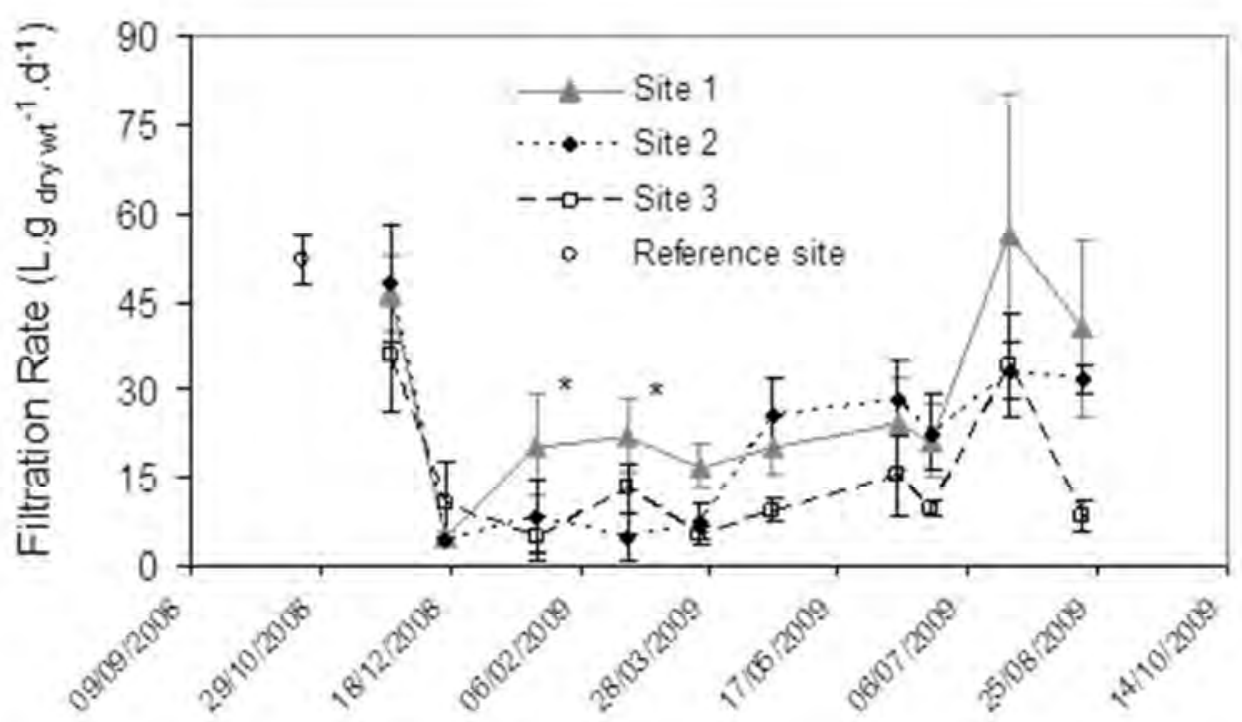

Figure 2: Filtration rate of the mussels exposed at the three sites (L.g $\left.{ }_{d r y}{ }^{-1} t^{-1} \cdot d^{-1}\right)$. Mean of three replicates (each composed of 5 mussels) $\pm S D$. The asterisks * indicate that the values are significantly different between Site 1 and Site 3 in February and between Site 1 and Site 2 in March (Kruskal and Wallis analysis, $p<0.05$ ).

\subsection{Metal contamination in mussels}

Despite a significant difference in the metal contamination of water and suspended particles over the 11-month exposure (Table 2), no significant difference in metal body burdens was observed between the sites (Figure 3) (Kruskall and Wallis analysis, p>0.05). The mean \pm SD body burdens during exposure, all sites considered, were $0.8 \pm 0.2 \mu \mathrm{g} . \mathrm{g} \mathrm{dry} \mathrm{wt}^{-1}$ for $\mathrm{Cd}, 1.0 \pm$ $0.4 \mu \mathrm{g} . \mathrm{g}_{\text {dry wt }}{ }^{-1}$ for $\mathrm{Cr}, 11.5 \pm 2.1 \mu \mathrm{g} . \mathrm{g}_{\text {dry wt }}{ }^{-1}$ for $\mathrm{Cu}, 7.4 \pm 2.7 \mu \mathrm{g} . \mathrm{g} \mathrm{dry} \mathrm{wt}^{-1}$ for $\mathrm{Ni}$ and $106.7 \pm$ $11.8 \mu \mathrm{g} . \mathrm{g}_{\text {dry wt }}{ }^{-1}$ for $\mathrm{Zn}$. The metal concentrations in zebra mussels were similar to those previously obtained for transplanted mussels along an affluent of the Seine River (Bourgeault et al., 2010b). These concentrations, as the concentrations measured in the present study, were similar to the metal contamination of mussels from reference sites in other studies (Camusso et al., 2001; De Lafontaine et al., 2000; Voets et al., 2006), even though the Seine River basin is subjected to very high anthropogenic pressure (Meybeck et al., 2007). This highlights the complexity of urbanized sites, which are undoubtedly contaminated, but with numerous 
substances at low concentrations levels and are therefore not strongly contrasted sites as regards to one specific substance.

A decrease of $\mathrm{Cd}, \mathrm{Cr}$ and $\mathrm{Cu}$ body burden is observed in April, as the same time as maximal weight of mussel - and consequently maximum CI. It can thus be inferred that the mussels' growth had induced a biological dilution of metals (Bourgeault et al., 2010b). Conversely, metal body burdens increase in June presumably as a consequence of spawning (Phillips, 1980).
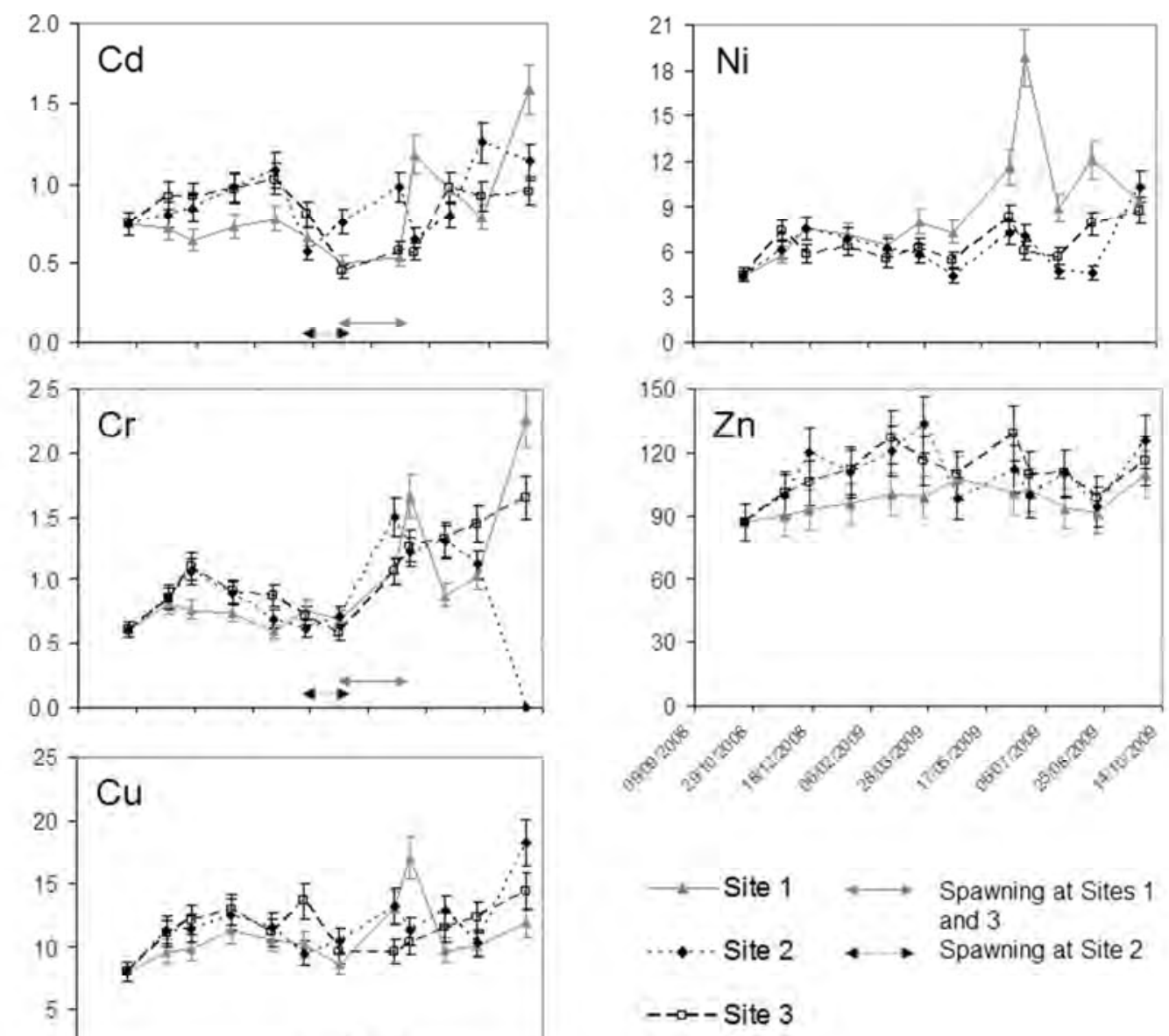

Figure 3: Metal concentrations in mussels $\left(\mu \mathrm{g} . \mathrm{g}_{\mathrm{dry}} \mathrm{wt}^{-1}\right)$ over the 11-month exposure at Site 1 (Marnay-sur-Seine), Site 2 (Bougival) and Site 3 (Triel-sur-Seine), and spawning period as indicated by a decreased condition index. 


\section{Discussion}

Through a comparison of observed versus predicted bioaccumulation, our objective is to assess the effectiveness of laboratory derived $\mathrm{AE}$ and/or sequential extraction to real field situations. Such a comparison will allow us to assess the actual bioavailability of particulate metals to zebra mussels.

With metal particulate concentration measured in the Exch + Red fractions of the sequential extraction and biodynamic parameters from the literature (Table 1), the model described by Eq. (3) and (4) strongly overestimated the metal body burden of the mussel (Figure 4 A).

Moreover, for $\mathrm{Cd}$ and $\mathrm{Zn}$ more than $78 \%$ of metal is accumulated from the trophic way showing that the key to better predict the bioaccumulation relies on the accurate determination of trophic exposure.

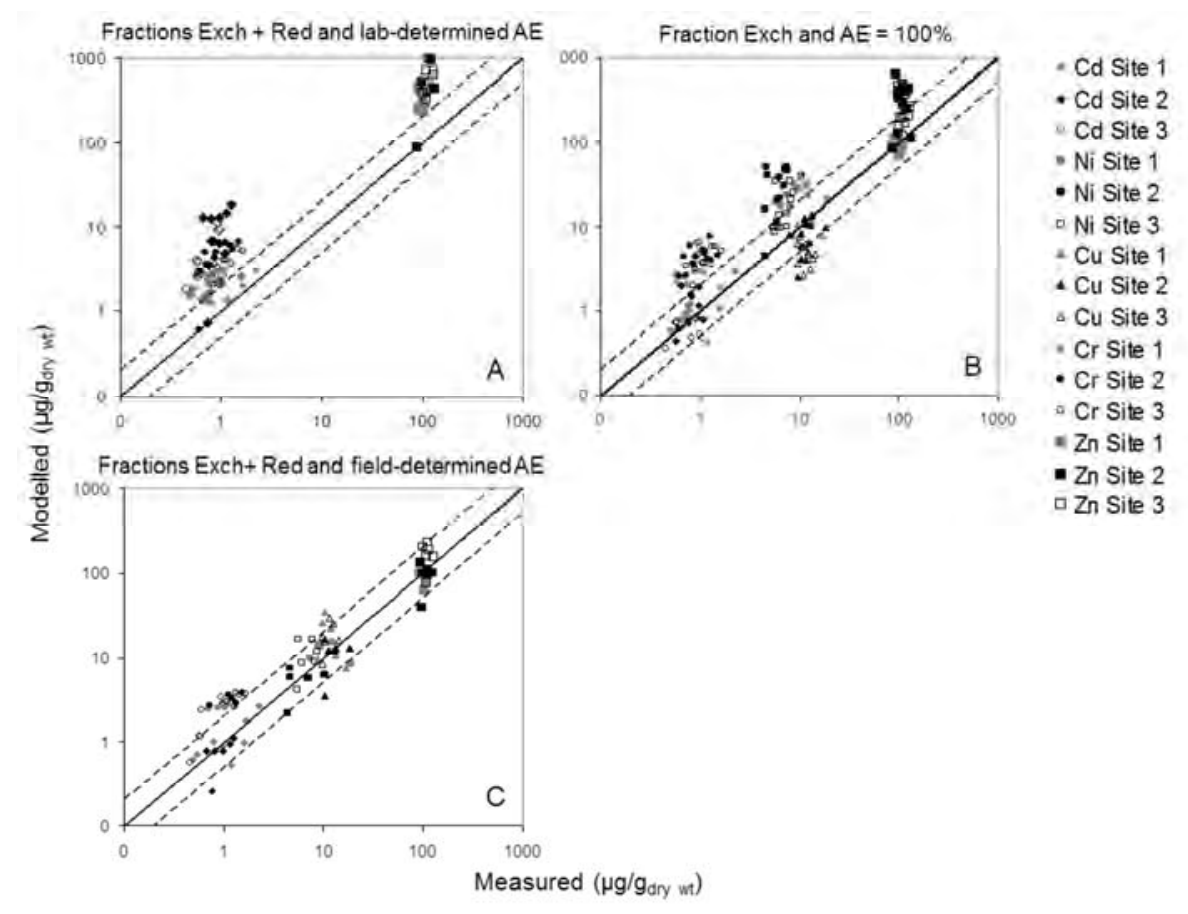

Figure 4: Measured and modelled metal concentrations in mussel tissues $\left(\mu g g_{d r y}{ }^{-1}{ }^{-1}\right)$ as a function of assimilation efficiency (AE) and concentration of particulate metals. The concentration of particulate metals is equal to the metal concentration measured in the different fractions of the chemical sequential extraction (Exchangeable: Exch., Reducible: Red). The assimilation efficiencies are 100\%, the laboratory-determined AE from the 
literature or the field-determined AE from in situ data. The solid line represents a 1:1 ratio and the broken lines correspond to a deviation of 2 above or below this line.

\subsection{Does chemical sequential extraction mimic the bioavailability of particulate metals?}

Assuming that the bioavailability of particulate metals would be properly assessed by a weak and selective extraction, as performed in the first steps of sequential extraction, a 100\% AE combined with the concentration of particulate metals in selected fraction of the sequential extraction would be sufficient to adjust the modelled data to the measured one.

Considering the concentration of particulate metals as the concentration measured in the Exch fraction only the predicted values in the mussel tissues were in the same order of magnitude as measured values (Figure 4 B). However, 35\% of predicted values are more than 3 times higher than the measured values (comparisons over time for the 3 sites are given in SI). For example, $\mathrm{Cr}$ and Ni contaminations are always overestimated, which suggests that metals in the exchangeable fraction are not fully bioavailable. Conversely, $\mathrm{Cu}$ in mussel tissue is well simulated for Site 1 and tends to be underestimated for Sites 2 and 3, which means that $\mathrm{Cu}$ contained in other than exchangeable fraction is probably also bioavailable at these sites. Hence, representing the bioavailability of particulate metals by the concentration in the exchangeable fraction only was not sufficient to accurately predict metal accumulation in organisms at all sites during the whole experiment.

Thus, in the present study, the speciation defined only by the chemical extraction, independently from the site and the metal considered, was found to be an unreliable predictor of the bioavailability of particulate metals.

The simulations presented in Figure 4 B are conditioned by the assumed accuracy of model parameters, i.e. $\mathrm{k}_{\mathrm{u}}$ and $\mathrm{k}_{\mathrm{e}}$. This assumption seems realistic for the elimination constant which varies over a small range with environmental conditions (Roditi and Fisher, 1999). However, 
$\mathrm{k}_{\mathrm{u}}$ is largely conditioned by the environmental chemistry (Bourgeault et al., 2010a). The $\mathrm{k}_{\mathrm{u}}$ variability has not been fully taken into account in the simulations, especially for $\mathrm{Zn}, \mathrm{Cu}$ and Cr. In order to investigate if a modification of $\mathrm{k}_{\mathrm{u}}$ can improve the model predictions, we considered an extreme case where there is no accumulation from the dissolved pathway. Since the diet-borne uptake of metal is predominant, the absence of dissolved accumulation (i.e. $\mathrm{k}_{\mathrm{u}}=0$ ) did not improve the metal accumulation predictions. The lack of dissolved Ni, Cd, and $\mathrm{Cu}$ accumulation (i.e., $\mathrm{k}_{\mathrm{u}}=0$ ) did not improved the fit of the data (see Figure 5 for the example of $\mathrm{Ni}$ at Site 3). With regard to $\mathrm{Zn}$ and $\mathrm{Cr}$, a lack of dissolved accumulation improved the prediction, especially for Site 2 and 3, but still lead to an overestimation of the accumulation. For instance, the model overestimated the accumulated Cr in Site 3 by a 3.7 factor if considering an accumulation from the dissolved pathway and by a 1.4 factor without dissolved accumulation (Figure 5 B). Given these results, we have not considered appropriate to revise the previously chosen values of $\mathrm{k}_{\mathrm{u}}$.

\subsection{Need for site-specific assimilation efficiencies in biodynamic modelling}

The difficulties in evaluating the bioavailability of particulate metals on the basis of a chemical speciation approach highlight the fundamental role of the AE parameter. We observed that the application of the biodynamic model with AEs from the literature and the particulate metal concentration measured in the Exch. + Red fractions leads to an overestimation of metal accumulation in organisms (Figure 4 A). Moreover, this overestimation is greater at Sites 2 and 3 than at Site 1 (see details of the simulation over time in Supporting Information). For example, Cd concentrations in mussels are overestimated on average by a factor of 3,13 and 6 at Sites 1, 2 and 3 respectively. It is important to notice that these variations from one site to another do not result from a variable water-borne accumulation of the metal (Cd and Ni) due to the site chemistry (Bourgeault et al., 2011; 
Bourgeault et al., 2010a). Indeed, the fact that $\mathrm{Zn}$ and Ca competition were included in $k_{u}$ estimation resulted in a reduced Cd uptake rate constant at Sites 2 and 3, and yet bioaccumulation of $\mathrm{Cd}$ and $\mathrm{Ni}$ at Sites 2 and 3 are the most overestimated ones. The particles characteristics (e.g. surface binding sites; concentrations of organic matter, sulfides and metals) and the biological behaviour of organisms, which probably differs between sites, may presumably explain the differences in the model accuracy between sites. We thus concluded that the application of variable AEs between sites is necessary to get accurate predictions of the biodynamic model.

The use of an optimized AE for each site and for each metal leads to a good match between predicted and measured concentrations (Figure $4 \mathrm{C}$ ). Indeed, $86 \%$ of the values predicted for the last 6 months of exposure were similar to the actual measured concentrations, within a 2fold factor. AEs optimized from the first 5 months of exposure are reported in Table 3. Optimized AEs were at least 3 times smaller than laboratory-determined AEs from the literature (Table 1). This confirms that the assimilation of metals freshly spiked onto particles in the laboratory is higher than that of natural particulate metals (Griscom et al., 2000). AEs at Site 1 were higher than those at the two downstream sites, even though sequential extractions tend to show that metals were more labile downstream (Priadi et al., 2011a). To determine the major driving factor explaining the different optimized AEs, a Partial Least Square (PLS) analysis was performed between the response (i.e., optimized AE) and independent variables (i.e., FR, chlorophyll, POC, DOC, TSS, pheopigment concentration, percentage of carbon in particles, temperature and $\mathrm{pH}$ ). Despite the upstream/downstream differences observed with both optimized AE and biological and physico-chemical parameters, no correlation could be established. However, we can hypothesize that the lower trophic level at Site 1 might result in a greater uptake of carbon, and thus a higher uptake of metals (Reeders et al., 1989). It can be noticed that, except for $\mathrm{Cu}$ at Site 1 and $\mathrm{Ni}$ at Site 3, AEs optimized from the first 5 months of 
exposure are close to AEs obtained from the calibration data corresponding to 11 months of exposure or the last 5 months (Table 3). This indicates that the biological cycle of the organism, which strongly varies through the year, may have less influence on metal AEs than site-specific environmental conditions. Practically speaking, a 6 month-exposure would be sufficient to determine site-specific AEs.
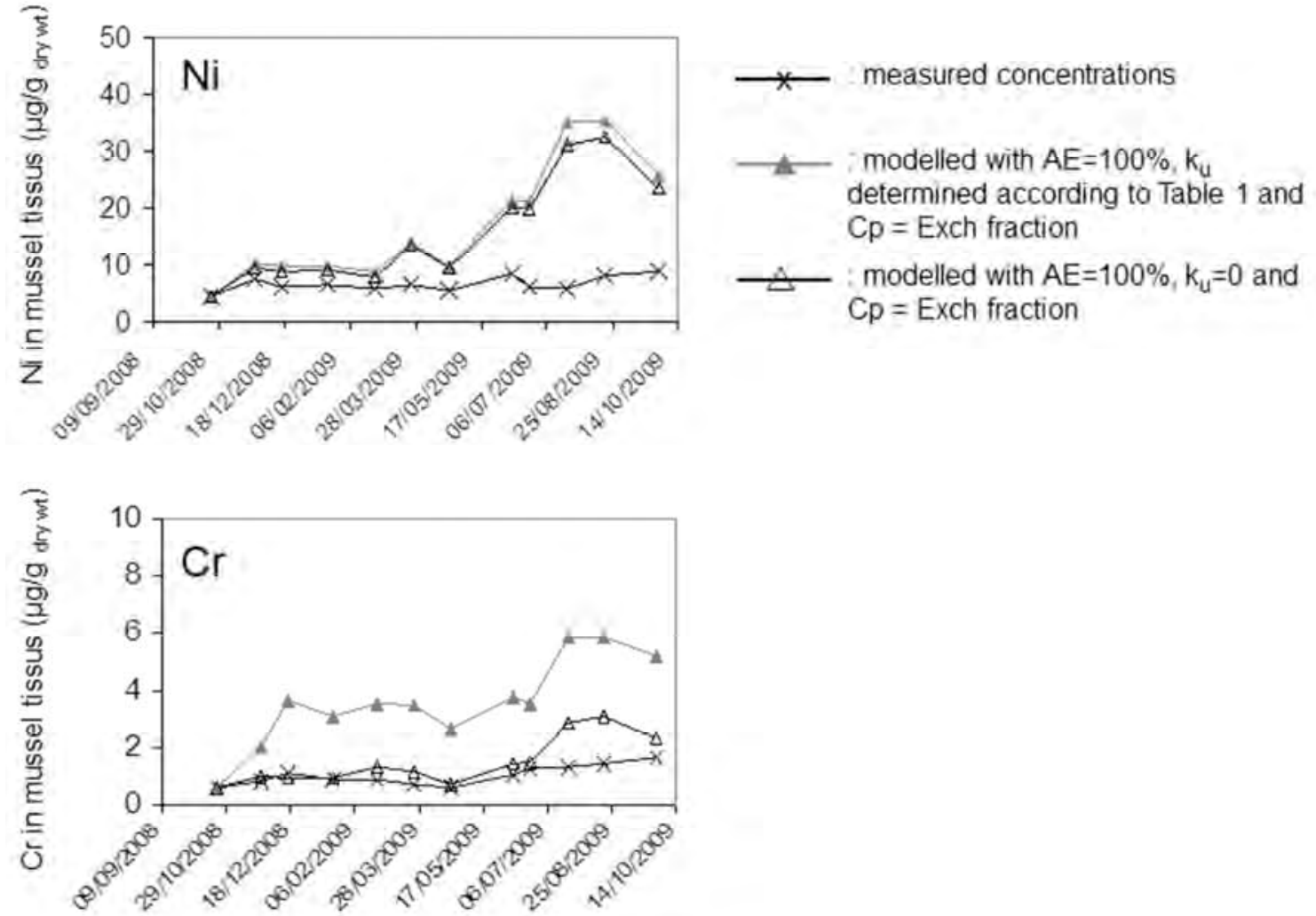

Figure 5: Measured and modelled Ni and Cr concentration in mussel tissue over the exposure at Site $3\left(\mu \mathrm{g} \mathrm{g}^{-1}\right)$ and effect of the absence of dissolved route on the modelled values. 
Table 3: Assimilation efficiencies (AE) obtained through the optimisation of predicted concentrations with the measured ones over the first 5 months, the last 5 months and the whole 11 months of exposure.

$\begin{aligned} & \text { Optimisation over the first 5- Optimisation from the last } \\ & \text { month exposure } \\ & \text { 5-month exposure }\end{aligned}$
month exposure

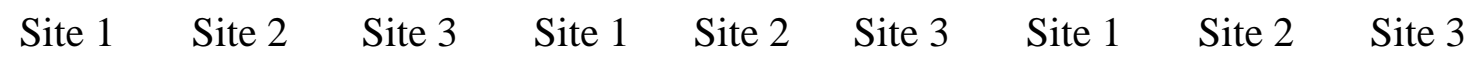

\begin{tabular}{llllllllll}
\hline $\mathrm{Cd}$ & $9 \%$ & $1 \%$ & $7 \%$ & $11 \%$ & $2 \%$ & $2 \%$ & $9 \%$ & $2 \%$ & $4 \%$ \\
$\mathrm{Cr}$ & $0 \%$ & $0 \%$ & $0 \%$ & $0 \%$ & $0 \%$ & $0 \%$ & $0 \%$ & $0 \%$ & $0 \%$ \\
$\mathrm{Zn}$ & $5 \%$ & $0 \%$ & $0 \%$ & $0 \%$ & $0 \%$ & $0 \%$ & $5 \%$ & $0 \%$ & $0 \%$ \\
$\mathrm{Ni}$ & $13 \%$ & $3 \%$ & $14 \%$ & $8 \%$ & $4 \%$ & $5 \%$ & $13 \%$ & $3 \%$ & $14 \%$ \\
$\mathrm{Cu}$ & $26 \%$ & $2 \%$ & $8 \%$ & $9 \%$ & $2 \%$ & $3 \%$ & $9 \%$ & $2 \%$ & $5 \%$ \\
\hline
\end{tabular}

\section{Conclusion}

This study highlights the difficulties in using generic biodynamic parameters and proposes an original methodology to determine site-specific AEs and to provide a good fit between the biodynamic model predictions and bioaccumulation measurements. This original methodology for estimating AE requires, above all, a robust biodynamic model with precisely determined kinetic constants ( $k_{u}, k_{e}$ and IR). Obtaining this robust model is not straightforward. Yet, this methodology enables the assessment of the actual assimilation efficiency of metals, taking into account both the effects of organism physiology and the geochemical variations in the speciation of particulate metals.

ACKNOWLEDGMENTS: The authors thank Emmanuelle Uher and Aurélie Germain for their support in field work and sample analysis, Julien Guieu for his linguistic support and the S.I.A.A.P. for providing access to Site 2 (Bougival). This work is part of the Piren-Seine research program and the MEDISIS (Métaux dissous en Seine) project, in the context of the 
EC2CO (Ecosphère Continentale et Côtière) program. A. Bourgeault acknowledged a PhD grant from the Ile-de-France Regional Council (R2DS program). We are grateful to the helpful and insightful comments from two referees.

In Supporting Information (SI) are reported the concentrations of labile and particulate metals over the whole exposure period, as well as the percentage of metals in the exchangeable and the reducible fractions at the three sites. The different outputs of bioaccumulation simulations over time are also presented, as is the theoretical resolution of the differential equations used for these simulations. 


\section{Literature Cited}

Ahlf, W., Drost, W., Heise, S., 2009. Incorporation of metal bioavailability into regulatory frameworks-metal exposure in water and sediment. Journal of Soils and Sediments 9, 411419.

Arifin, Z., Bendell-Young, L.I., 1997. Feeding response and carbon assimilation by the blue mussel Mytilus trossulus exposed to environmentally relevant seston matrices. Marine Ecology Progress Series 160, 241-253.

Arifin, Z., Bendell-Young, L.I., 2000. Influence of a selective feeding behaviour by the blue mussel Mytilus trossulus on the assimilation of ${ }^{109} \mathrm{Cd}$ from environmentally relevant seston matrices. Marine Ecology Progress Series 192, 181-193.

Bervoets, L., Voets, J., Chu, S., Covaci, A., Schepens, P., Blust, R., 2004. Comparison of accumulation of micropollutants between indigenous and transplanted zebra mussels (Dreissena polymorpha). Environmental Toxicology and Chemistry 23, 1973-1983.

Bourgeault, A., Gourlay-Francé, C., Ayrault, S., Tusseau-Vuillemin, M.-H., 2011. Bioaccumulation of waterborne Ni in Dreissena polymorpha: a stable isotope experiment to assess the effect of water chemistry. Accepted for publication in Environmental Toxicology and Chemistry.

Bourgeault, A., Gourlay-Francé, C., Tusseau-Vuillemin, M.H., 2010a. Modeling the effect of water chemistry on the bioaccumulation of waterborne $\mathrm{Cd}$ in zebra mussels. Environmental Toxicology and Chemistry 29, 2182-2189.

Bourgeault, A., Gourlay-Francé, C., Vincent-Hubert, F., Palais, F., Geffard, A., BiagiantiRisbourg, S., Pain-Devin, S., Tusseau-Vuillemin, M.-H., 2010b. Lessons from a transplantation of zebra mussels into a small urban river: An integrated ecotoxicological assessment Environmental Toxicology 25, 468-478. 
Bryan, G.W., Langston, W.J., 1992. Bioavailability, accumulation and effects of heavy metals in sediments with special reference to United Kingdom estuaries. Environmental Pollution 76, $89-131$.

Camusso, M., Balestrini, R., Binelli, A., 2001. Use of zebra mussel (Dreissena polymorpha) to assess trace metal contamination in the largest Italian subalpine lakes. Chemosphere 44, 263-270.

Casado-Martinez, M.C., Smith, B.D., DelValls, T.A., Luoma, S.N., Rainbow, P.S., 2009. Biodynamic modelling and the prediction of accumulated trace metal concentrations in the polychaete Arenicola marina. Environmental Pollution 157, 2743-2750.

Christie, J.C., Bendell, L.I., 2009. Sources of dietary cadmium to the Pacific oyster Crassostrea gigas. Marine Environmental Research 68, 97-105.

Cooper, S., Hare, L., Campbell, P.G.C., 2010. Modeling cadmium uptake from water and food by the freshwater bivalve Pyganodon grandis. Can. J. Fish. Aquat. Sci. 67, 1874-1888.

Davison, W., Zhang, H., 1994. In situ speciation measurements of trace components in natural waters using thin-film gels. Nature 367, 546-548.

De Jonge, M., Blust, R., Bervoets, L., 2010. The relation between Acid Volatile Sulfides (AVS) and metal accumulation in aquatic invertebrates: Implications of feeding behavior and ecology. Environmental Pollution 158, 1381-1391.

De Lafontaine, Y., Gagné, F., Blaise, C., Costan, G., Gagnon, P., Chan, H.M., 2000. Biomarkers in zebra mussels (Dreissena polymorpha) for the assessment and monitoring of water quality of the St Lawrence River (Canada). Aquatic Toxicology 50, 51-71.

Di Toro, D.M., Mahony, J.D., Hansen, D.J., Scott, K.J., Carlson, A.R., Ankley, G.T., 1992. Acid volatile sulfide predicts the acute toxicity of cadmium and nickel in sediments. Environmental Science and Technology 26, 96-101. 
Fan, W., Wang, W.X., 2003. Extraction of spiked metals from contaminated coastal sediments: A comparison of different methods. Environmental Toxicology and Chemistry 22, 2659-2666.

Ferreira, D., Tousset, N., Ridame, C., Tusseau-Vuillemin, M.H., 2008. More than inorganic copper is bioavailable to aquatic mosses at environmentally relevant concentrations. Environmental Toxicology and Chemistry 27, 2108-2116.

Galstoff, P.S., 1928. Experimental study of the function of the oyster gills and its bearing on the problems of oyster culture, and sanitary control of the oyster industry. Bulletin U.S. Bur. Fish. 44, 1-39.

Griscom, S.B., Fisher, N.S., 2004. Bioavailability of sediment-bound metals to marine bivalve molluscs: An overview. Estuaries 27, 826-838.

Griscom, S.B., Fisher, N.S., Luoma, S.N., 2000. Geochemical influences on assimilation of sediment-bound metals in clams and mussels. Environmental Science and Technology 34, 9199.

Kryger, J., Riisgard, H.U., 1988. Filtration rate capacities in 6 species of European freshwater bivalves. Oecologia 77, 34-38.

Larner, B.L., Palmer, A.S., Seen, A.J., Townsend, A.T., 2008. A comparison of an optimised sequential extraction procedure and dilute acid leaching of elements in anoxic sediments, including the effects of oxidation on sediment metal partitioning. Analytica Chimica Acta $608,147-157$.

Luoma, S.N., 1989. Can we determine the biological availability of sediment-bound trace elements? Hydrobiologia 176-177, 379-396.

Luoma, S.N., Rainbow, P.S., 2005. Why Is Metal Bioaccumulation So Variable? Biodynamics as a Unifying Concept. Environmental Science and Technology 39, 1921-1931. 
Mayer, L.M., Chen, Z., Findlay, R.H., Fang, J., Sampson, S., Self, R.F.L., Jumars, P.A., Quetel, C., Donard, O.F.X., 1996. Bioavailability of sedimentary contaminants subject to deposit-feeder digestion. Environmental Science and Technology 30, 2641-2645.

Mersch, J., Morhain, E., Mouvet, C., 1993. Laboratory accumulation and depuration of copper and cadmium in the freshwater mussel Dreissena polymorpha and the aquatic moss Rhynchostegium riparioides. Chemosphere 27, 1475-1485.

Meybeck, M., Lestel, L., Bonté, P., Moilleron, R., Colin, J.L., Rousselot, O., Hervé, D., de Pontevès, C., Grosbois, C., Thévenot, D.R., 2007. Historical perspective of heavy metals contamination $(\mathrm{Cd}, \mathrm{Cr}, \mathrm{Cu}, \mathrm{Hg}, \mathrm{Pb}, \mathrm{Zn})$ in the Seine River basin (France) following a DPSIR approach (1950-2005). Science of the Total Environment 375, 204-231.

Pan, K., Wang, W.X., 2008. Validation of biokinetic model of metals in the scallop Chlamys nobilis in complex field environments. Environmental Science \& Technology 42, 6285-6290. Phillips, D.J.H., 1980. Quantitative Aquatic Biological Indicators: Their Use to Monitor Trace Metal and Organochlorine Pollution. Applied Science Publishers Ltd., London.

Priadi, C., Ayrault, S., Pacini, S., Bonte, P., 2011a. Urbanization impact of the Greater Paris Region on metal mobility in suspended sediments in the Seine River, France: Role of iron oxides. International Journal of Environmental Science and Technology 8, 1-18.

Priadi, C., Bourgeault, A., Ayrault, S., Gourlay-Francé, C., Tusseau-Vuillemin, M.-H., Bonté, P., Mouchel, J.M., 2011b. Spatio-temporal variability of solid, total dissolved and labile metal: passive vs. discrete sampling evaluation in river metal monitoring. Journal of Environmental Monitoring 13, 1470-1479.

Pueyo, M., Rauret, G., Lück, D., Yli-Halla, M., Muntau, H., Quevauviller, P., Lopez-Sanchez, J.F., 2001. Certification of the extractable contents of $\mathrm{Cd}, \mathrm{Cr}, \mathrm{Cu}, \mathrm{Ni}, \mathrm{Pb}$ and $\mathrm{Zn}$ in a freshwater sediment following a collaboratively tested and optimised three-step sequential extraction procedure. Journal of Environmental Monitoring 3, 243-250. 
Reeders, H.H., Bij de Vaate, A., 1990. Zebra mussels (Dreissena polymorpha): a new perspective for water quality management. Hydrobiologia 200-201, 437-450.

Reeders, H.H., Bij De Vaate, A., Slim, F.J., 1989. The filtration rate of Dreissena polymorpha (Bivalvia) in three Dutch lakes with reference to biological water quality management. Freshwater Biology 22, 133-141.

Roditi, H.A., Caraco, N.F., Cole, J.J., Strayer, D.L., 1996. Filtration of Hudson River water by the zebra mussel (Dreissena polymorpha). Estuaries 19, 824-832.

Roditi, H.A., Fisher, N.S., 1999. Rates and routes of trace element uptake in zebra mussels. Limnology and Oceanography 44, 1730-1749.

Roditi, H.A., Fisher, N.S., Sañudo-Wilhelmy, S.A., 2000. Field testing a metal bioaccumulation model for zebra mussels. Environmental Science and Technology 34, 28172825 .

Stecko, J.R.P., Bendell-Young, L.I., 2000. Uptake of ${ }^{109} \mathrm{Cd}$ from sediments by the bivalves Macoma balthica and Protothaca staminea. Aquatic Toxicology 47, 147-159.

Tusseau-Vuillemin, M.H., Gilbin, R., Bakkaus, E., Garric, J., 2004. Performance of diffusion gradient in thin films to evaluate the toxic fraction of copper to Daphnia magna. Environmental Toxicology and Chemistry 23, 2154-2161.

Tusseau-Vuillemin, M.H., Gourlay, C., Lorgeoux, C., Mouchel, J.M., Buzier, R., Gilbin, R., Seidel, J.L., Elbaz-Poulichet, F., 2007. Dissolved and bioavailable contaminants in the Seine river basin. Science of the Total Environment 375, 244-256.

Voets, J., Talloen, W., de Tender, T., van Dongen, S., Covaci, A., Blust, R., Bervoets, L., 2006. Microcontaminant accumulation, physiological condition and bilateral asymmetry in zebra mussels (Dreissena polymorpha) from clean and contaminated surface waters. Aquatic Toxicology 79, 213-225. 
Wang, W.-X., Fisher, N.S., 1998. Assimilation efficiencies of chemicals contaminants in aquatic invertebrates: a synthesis. Environmental Toxicology and Chemistry 18, 2034-2045. Wang, W.X., Fisher, N.S., Luoma, S.N., 1996. Kinetic determinations of trace element bioaccumulation in the mussel Mytilus edulis. Marine Ecology Progress Series 140, 91-113. Wang, W.X., Rainbow, P.S., 2008. Comparative approaches to understand metal bioaccumulation in aquatic animals. Comparative Biochemistry and Physiology - C Toxicology and Pharmacology 148, 315-323.

Wang, W.X., Yan, Q.L., Fan, W., Xu, Y., 2002. Bioavailability of sedimentary metals from a contaminated bay. Marine Ecology Progress Series 240, 27-38.

Zaroogian, G.E., Johnson, M., 1984. Nickel uptake and loss in the bivalves Crassostrea virginica and Mytilus edulis. Archives of Environmental Contamination and Toxicology 13, 411-418. 


\section{Supporting information}

Bioavailability of particulate metal to zebra mussels:

Biodynamic modeling shows that assimilation efficiencies are site-specific

Bourgeault Adeline, Gourlay-Francé Catherine, Priadi Cindy, Ayrault Sophie, and TusseauVuillemin Marie-Hélène

Number of Figures in SI: 4

Number of Tables in SI: 3 
Table S1: Background metal levels in zebra mussels collected from a reference site in the Meuse-Marne canal (France) $\left(\mu \mathrm{g} \cdot \mathrm{g}_{\mathrm{dry}} \mathrm{wt}^{-1}\right)$. Measurement realised on a pool of 25 mussels.

\begin{tabular}{cc}
\cline { 2 - 2 } & Reference site \\
\hline $\mathrm{Cd}$ & 0,74 \\
$\mathrm{Cr}$ & 0,61 \\
$\mathrm{Zn}$ & 87,22 \\
$\mathrm{Ni}$ & 4,48 \\
$\mathrm{Cu}$ & 8,03 \\
\hline
\end{tabular}


Table S2: Concentrations of labile ${ }^{a}$ and particulate ${ }^{b}$ metals over the 11-month exposure at Marnay (Site 1), Bougival (Site 2) and Triel (Site 3). An asterisk $(*)$ indicates that the values were extrapolated as explained in the materials and methods section.

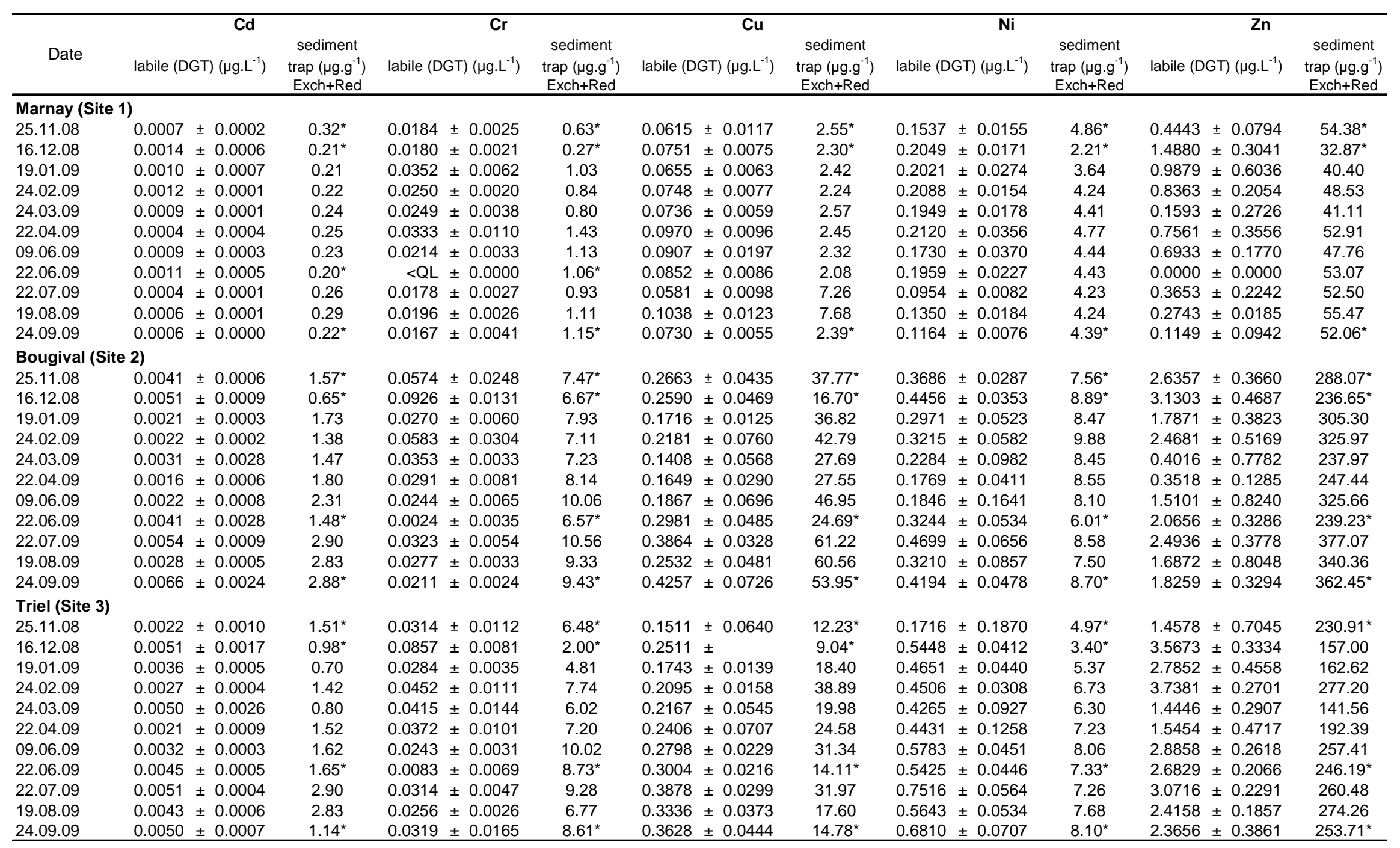


Table S3: Percentage of metals in the exchangeable and the reducible fractions of total suspended solids (TSS) collected with sediment traps (Priadi et al., 2011). Mean over the exposure \pm SD.

\begin{tabular}{lccc}
\cline { 2 - 4 } & Site 1 & Site 2 & Site 3 \\
\hline $\mathrm{Cd}$ & $82 \pm 6 \%$ & $88 \pm 1 \%$ & $88 \pm 6 \%$ \\
$\mathrm{Cr}$ & $7 \pm 1 \%$ & $25 \pm 2 \%$ & $28 \pm 5 \%$ \\
$\mathrm{Zn}$ & $64 \pm 5 \%$ & $84 \pm 1 \%$ & $84 \pm 4 \%$ \\
$\mathrm{Ni}$ & $40 \pm 4 \%$ & $45 \pm 3 \%$ & $45 \pm 5 \%$ \\
$\mathrm{Cu}$ & $21 \pm 12 \%$ & $39 \pm 3 \%$ & $41 \pm 9 \%$ \\
\hline
\end{tabular}

Priadi, C., Ayrault, S., Pacini, S., Bonte, P., 2011. Urbanization impact on metal mobility in riverine suspended sediment: Role of metal oxides International Journal of Environmental Science and Technology 8, 1-18. 


\section{Figures}
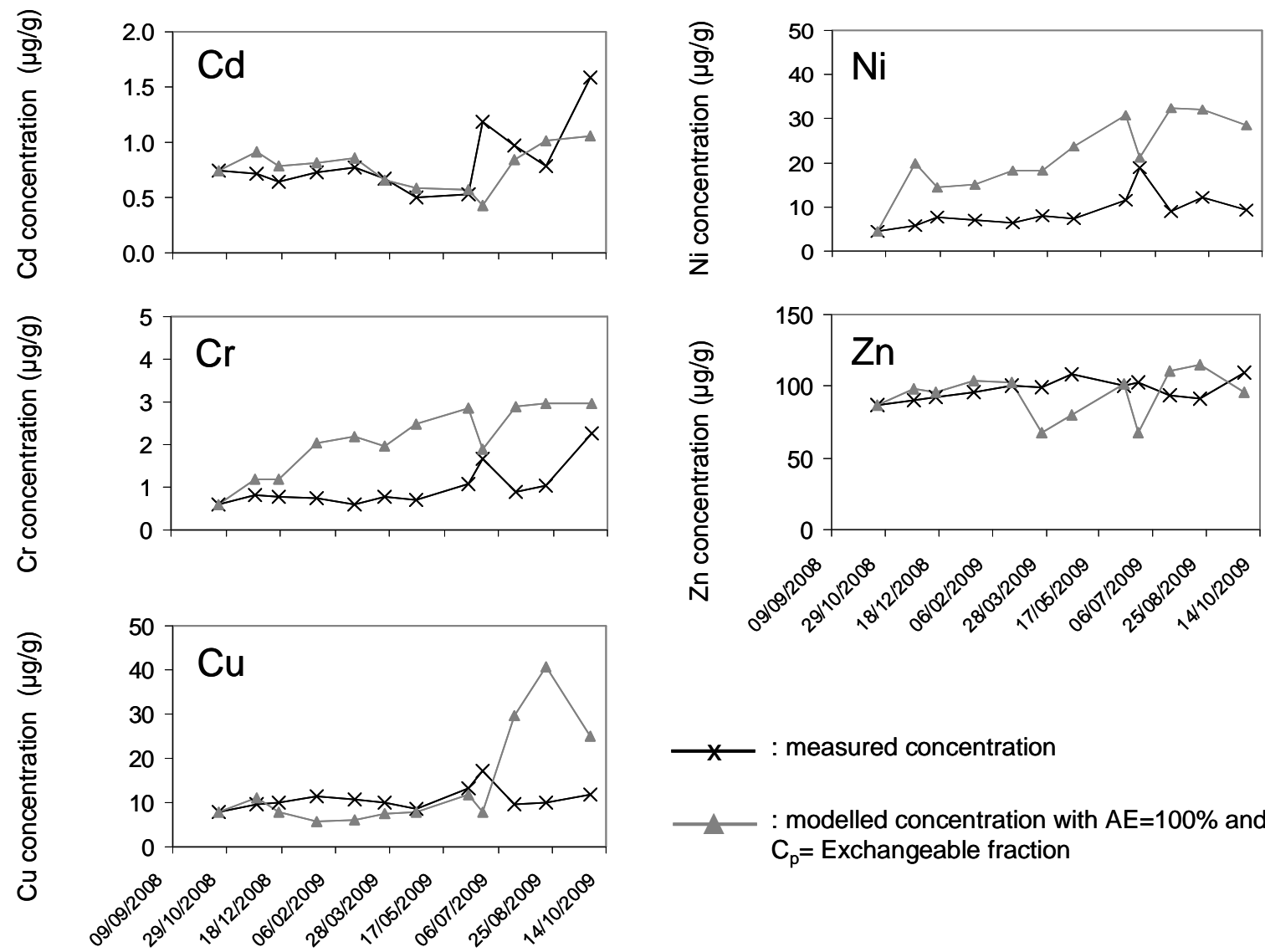

$\longrightarrow$ : measured concentration

- modelled concentration with $\mathrm{AE}=100 \%$ and $\mathrm{C}_{\mathrm{p}}=$ Exchangeable fraction

Figure S1: Measured and modeled metal concentrations in mussel tissue $\left(\mu \mathrm{g} \cdot \mathrm{g}_{\mathrm{dry}} \mathrm{wt}^{-1}\right)$ at Site 1 with $\mathrm{AE}=100 \%$ and the metal contamination being considered as the concentration measured in the exchangeable fraction. 

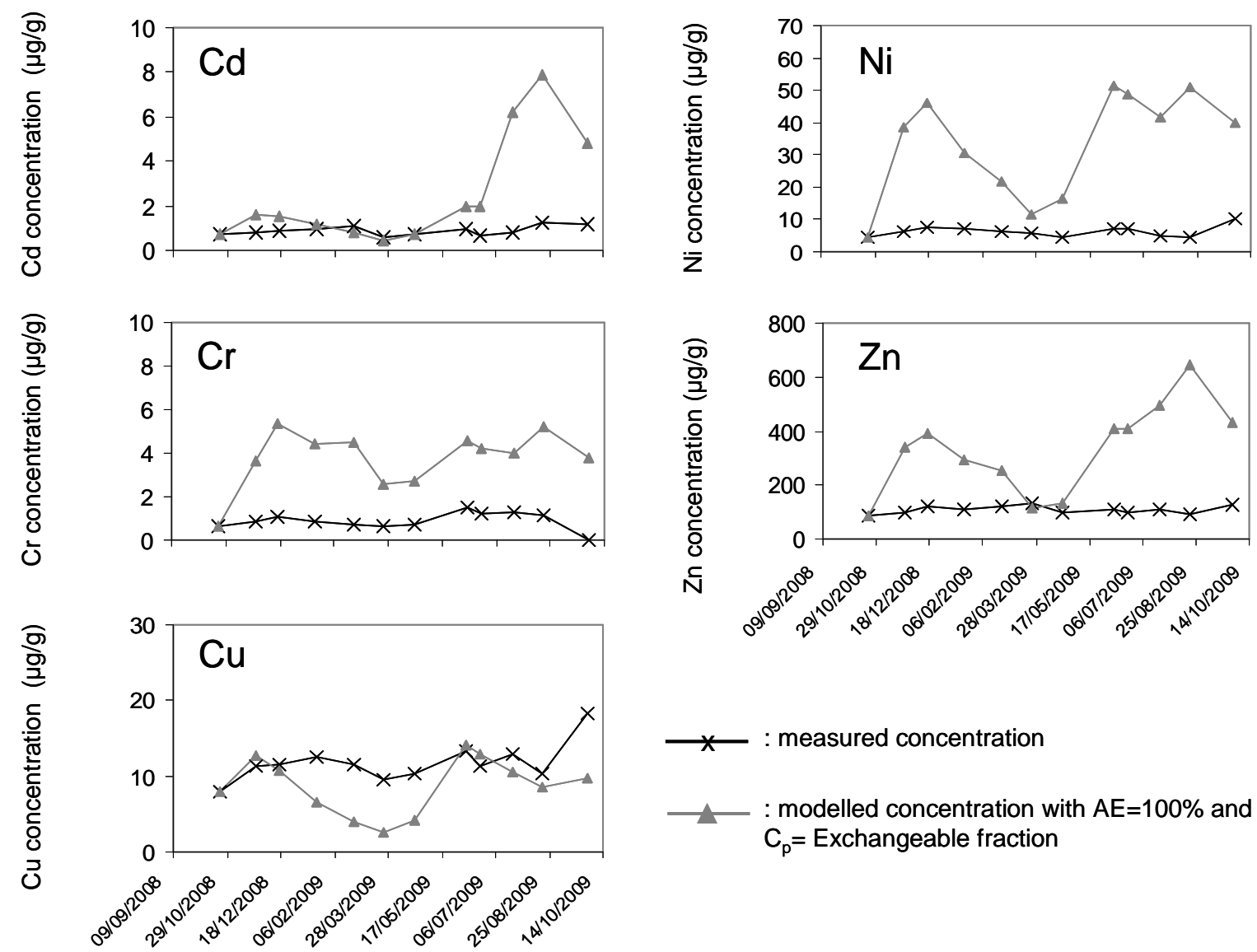

$\longrightarrow$ : measured concentration : modelled concentration with $\mathrm{AE}=100 \%$ and
$\mathrm{C}_{\mathrm{p}}=$ Exchangeable fraction

Figure S2: Measured and modeled metal concentrations in mussel tissue $\left(\mu \mathrm{g} \cdot \mathrm{g}_{\mathrm{dry}} \mathrm{wt}^{-1}\right.$ ) at Site 2 with $\mathrm{AE}=100 \%$ and the metal contamination being considered as the concentration measured in the exchangeable fraction. 

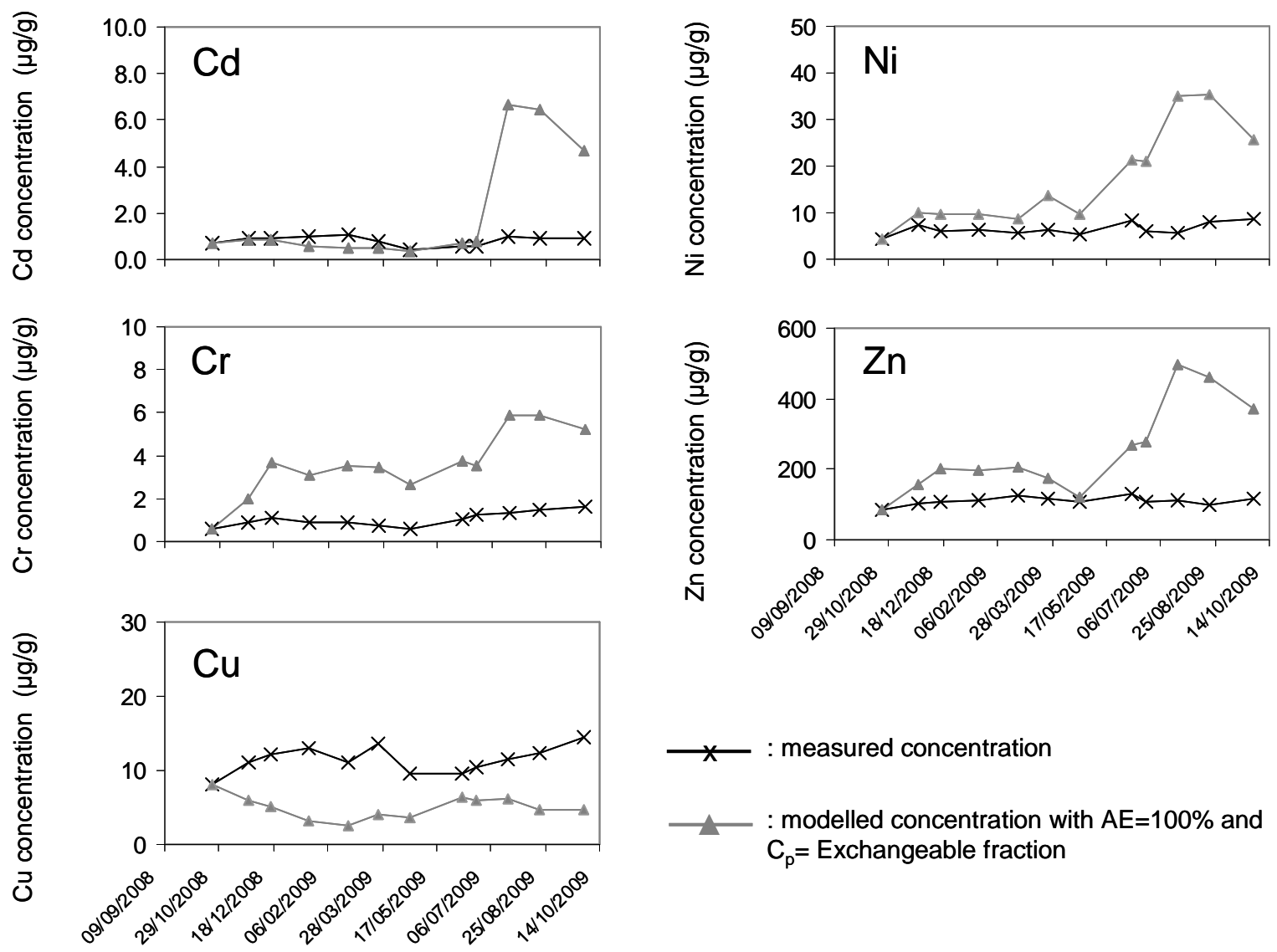

$\longrightarrow$ : measured concentration

: modelled concentration with $\mathrm{AE}=100 \%$ and $\mathrm{C}_{\mathrm{p}}=$ Exchangeable fraction

Figure S3: Measured and modeled metal concentrations in mussel tissue $\left(\mu \mathrm{g} \cdot \mathrm{g}_{\mathrm{dry}} \mathrm{wt}^{-1}\right)$ at Site 3 with $\mathrm{AE}=100 \%$ and the metal contamination being considered as the concentration measured in the exchangeable fraction. 

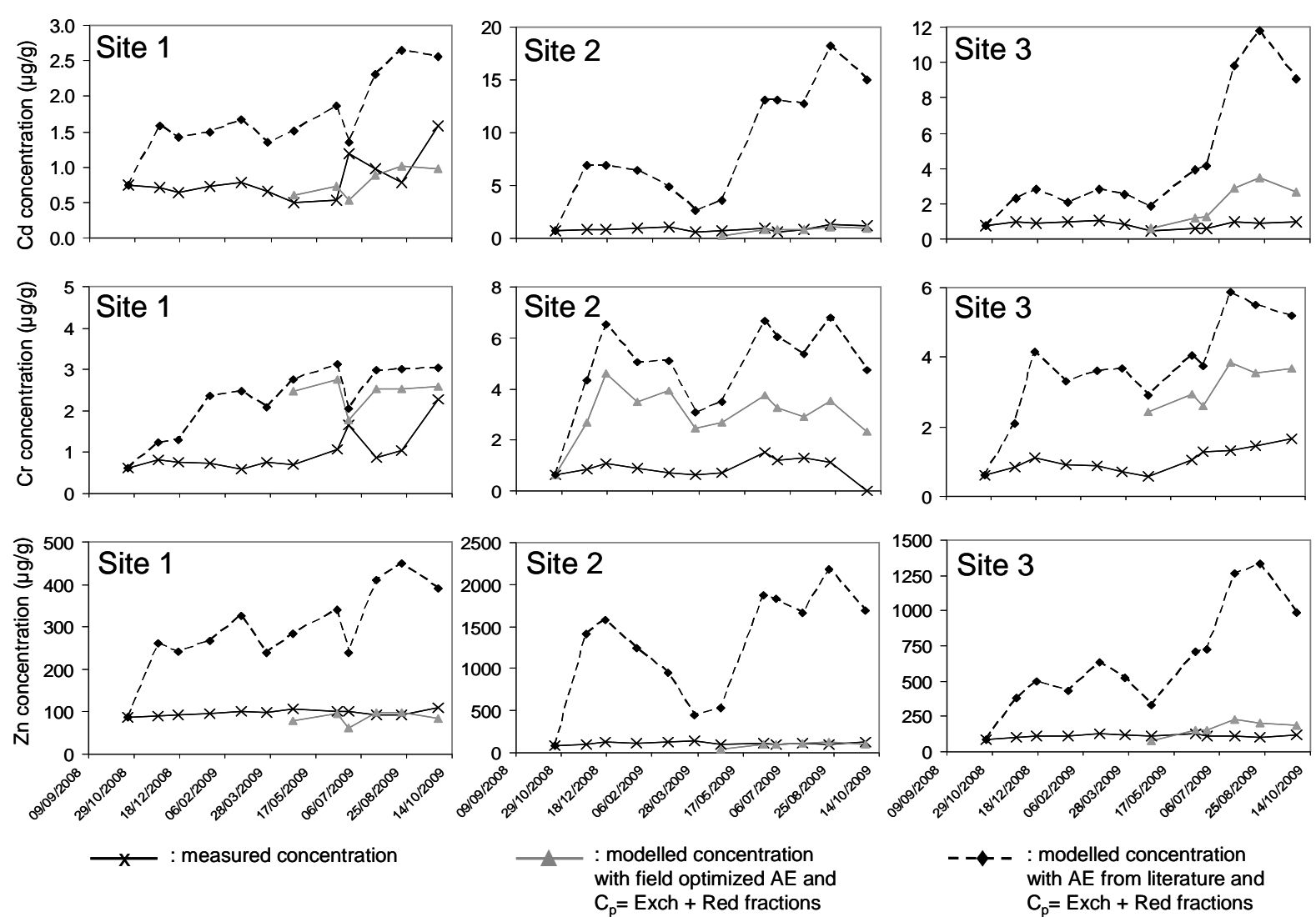

Figure S4: Measured and modeled metal concentrations in mussel tissue $\left(\mu \mathrm{g} \cdot \mathrm{g}_{\mathrm{dry}} \mathrm{wt}^{-1}\right)$ with AE from the literature or from optimization of field data. 


\section{Resolution of the first order differential equation}

The biodynamic differential equation is :

$\frac{d C_{m}}{d t}=k_{u} \cdot C_{w}+A E \cdot I R \cdot C_{f}-\left(k_{e}+g\right) \cdot C_{m}$

Eq. (S1)

It can be re-written as

$\frac{d C_{m}}{d t}+\left(k_{e}+g\right) \cdot C_{m}=\left(k_{e}+g\right) \cdot C_{m_{-} s}$

with $C_{m_{-} s s}=\frac{k_{u} \cdot C_{w}+A E \cdot I R \cdot C_{f}}{k_{e}+g}$

Since $C_{w}$ and $C_{f}$ are monthly-average concentrations, they are constant between two time-steps. Hence, between $\mathrm{t}_{\mathrm{i}-1}$ and $\mathrm{t}_{\mathrm{i}}, C_{m_{-} s s}$ is a constant.

The generic solution of a differential equation of the $y^{\prime}+a y=b$ type is $y=\alpha \cdot e^{-a x}+\frac{b}{a}$

Hence, between $t_{i-1}$ and $t_{i}$, where $C_{m-s s}$ is a constant, the solution of Equation (3) is:

$C_{m}(t)=\alpha \cdot e^{-\left(k_{e}+g\right) t}+C_{m_{-} s s}$

Eq. (S4)

At time $t_{i-l}$ the concentration in mussels is given by

$C_{m}\left(t_{i-1}\right)=\alpha \cdot e^{-\left(k_{e}+g\right) t_{i-1}}+C_{m_{-} s s}$

This enables the expression of $\alpha$ as a function of $C_{m-s s}$ and $C_{m}\left(t_{i-1}\right)$

$\alpha \cdot=\frac{C_{m}\left(t_{i-1}\right)-C_{m_{-} s s}}{e^{-\left(k_{e}+g\right) t_{i-1}}}$

Eq. (S6) 
With a combination of Equation 5 and Equation 7, $C_{m}\left(t_{i}\right)$ can be expressed as

$C_{m}(t)=\frac{C_{m}\left(t_{i-1}\right)-C_{m_{-} s s}}{e^{-\left(k_{e}+g\right) t_{i-1}}} \cdot e^{-\left(k_{e}+g\right) t}+C_{m_{-} s s}$

Eq. (S7)

$C_{m}\left(t_{i}\right)=\left(C_{m}\left(t_{i-1}\right)-C_{m_{-} s s}\right) \cdot e^{-\left(k_{e}+g\right) \cdot\left(t_{i}-t_{i-1}\right)}+C_{m_{-} s s}$

Finally,

$C_{m}\left(t_{i}\right)=C_{m}\left(t_{i-1}\right) \cdot e^{-\left(k_{e}+g\right) \cdot\left(t_{i}-t_{i-1}\right)}+C_{m_{-} s s} \cdot\left(1-e^{-\left(k_{e}+g\right) \cdot\left(t_{i}-t_{i-1}\right)}\right)$

Eq. (S9) 